\title{
PRESIDENT PURDY'S VIEWS ON RECONSTRUCTION
}

$\mathbf{P}^{\mathrm{n}}$

RESIDENT PURDY of the National Municipal League was unable to attend the Rochester Conference on account of illness in his home. His views on the general subject considered are contained in the following letter:

105 East 22d Street,

Nww YoRK, November 18, 1918.

I am grieved that I am deprived of the honor of presiding at the opening meeting of the conference of the League. It would have been a privilege and a pleasure to have said a few words about the policy and purpose of reconstruction. Our conference will have little, if anything, to say about the difficult task of demobilization. When the army returns to civil life and the munition makers to peaceful trade, the great change must be planned so that the ordinary business of the country shall be as little disturbed as possible. These plans are vital; they are necessary; but however well they may be carried out their purpose is only to restore order. These plans do not in themselves prepare us for any better civilization than that to which we were accustomed.

Our conference has been called to turn public attention toward a study of plans for our future lives which shall make the lives of men and women better and happier than they were before. We must consider constitutions and laws, charters and codes, that obstacles to progress may be removed and that, so far as action by states and cities may add to and diffuse prosperity, such action shall be taken. We should take thought about the conditions controlling the lives of wage-earners, both organized and unorganized, about public utilities, and the relation of wage-earners to the administration of public utilities whether they are administered as governmental agencies or by private corporations. Public utilities are quasi-governmental agencies even when privately administered, and never again must their public nature be neglected. They should be dealt with as natural monopolies. There is no room for competition in the transportation of passengers or goods or in the transmission of intelligence.

The policies that are adopted to meet the present emergency with reference to the public lands and to all our natural resources-land, water, forest, and mine-are of pre-eminent importance to the welfare of the people now and for the future. Speaking generally, no natural resources now owned by the nation or by any state should ever be alienated in perpetuity but should be operated by a governmental agency or under lease for reasonable terms on just compensation.

The war has forced upon us a more adequate attention to public health 
than ever before. There is great danger that we shall sink back to the point from which we started. Every gain that has been made in the conservation of the health of our people should be preserved and should be made the starting point for further gains. We cannot have public health without adequate and suitable houses for wage-earners. We have improved our standards of housing. There will be great pressure brought to bear to break down those standards on the theory that houses of such high standard cannot be built at a profit. If that be true, let them be built with public money. However they may be built, never again must we permit such disregard of the health, safety, and morals of the people as has been common in the past.

Sincerely yours,

Lawson Purdy,

President.

\section{STORY OF THE ROCHESTER CONFER- ENCE AND AFTER}

BY CLINTON ROGERS WOODRUFF

Philadelphia

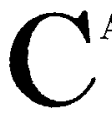

ALLED while the Great War was in full progress, and before an early armistice was thought of, even by the most hopeful, the Rochester Conference on American Reconstruction Problems came just at the conclusion of hostilities and when the minds of the American people were full of the joy of peace and victory, and were just beginning to think of readjustment on a peace basis. Originally intended to direct attention to the necessity for careful thought about the after-war period, it came at its actual beginning. Perhaps I can best describe the thoughts in the minds of those who were responsible for the meeting by quoting from a letter written by the chairman of the National Municipal Leagues' Committee on Reconstruction (LeRoy E. Synder, of Rochester) in July, 1918:

I am under the necessity of trying to state my views on reconstruction when they are still in progress of formulation.

As I see it, the fundamental basis of reconstruction is philosophicalof the spirit. Let us assume that the soldier who returns from France, who has perhaps been maimed or has lost friends and relatives, has given several valuable years of his own life to the war, will raise the question, "What is this all about?" He will be told that he has been fighting for Democracy. It thus becomes necessary for those of us who pretend to be of some consequence in helping shape public opinion to get at the business of finding out what Democracy means, not in the abstract but in the concrete - what it means for the United States of America in 1919, or $1920,1921$.

It is of course impossible to say whether the people of this country 